\title{
How Foreign Languages Influence Vietnamese in Bac Lieu
}

\author{
Anh Van Truong \\ ${ }^{1}$ Department for Foreign Languages, Sai Gon University \\ ${ }^{*}$ Corresponding author. Email: tvanh@sgu.edu.vn
}

\begin{abstract}
That many languages are used in society, especially in developed communities, is a natural phenomenon. Bac Lieu, a small province, does not escape this natural law. On the way of development, the languages of Bac Lieu communities are growing. Then, there is a need for language interference to make the Vietnamese language not hybrid but increasingly luxuriant. Selecting and borrowing new words from other languages can make our mother tongue richer and more beautiful. However, it should be a careful refinery so that our language's identity and nuances will be kept unchanged.
\end{abstract}

Keywords: Borrowed word, cross-language, interference, language.

\section{INTRODUCTION}

Vietnam has complex linguistic geography. There are three main regions and 64 cities and provinces in Vietnam. In the provinces and cities, people use many languages and many dialects. Although most people learn and speak Vietnamese at school, they are encouraged to use other languages such as English, Chinese, Khmer, Champa, Ede, H'Mong, Thai, etc. The authorities motivate ethnic minorities to learn and use their mother tongues and foreign languages to make the languages in Vietnam more colorful and abundant.

As a newly-discovered land, Bac Lieu was founded about 300 years ago. The following verse describes Bac Lieu quite clearly at that time:

Monkeys climbed in the trees of Bac Lieu Crocodiles swam in the rivers, and tigers roared on the banks.

As of that time, the Khmer, the Vietnamese, the Chinese ... and other ethnic peoples arrived to settle and establish their life in this countryside. Up to now, the inhabitants of Bac Lieu have been composed of 947,538 people (according to the report of Bac Lieu Statistical Office in 2020).

Vietnamese is always the main language of communication, followed by Khmer and Chinese. As France occupied western, southern provinces, they brought troops here to dominate and occupy key positions in the protectorate. At school, French was taught officially. Those who learned then only spoke and wrote French. Later on, Vietnamese was introduced to teaching. During the 1940s, students studied two parallel languages, English and French. After 1975, in addition to English and French, students could choose Russian as a foreign language. Although Chinese and Khmer are not officially taught in public schools, their communities build their own bases to teach their mother tongue.

Thus, in addition to Vietnamese as a compulsory official language, French, English, Russian, Khmer, and Chinese have coexisted. These languages have more or less influenced Vietnamese. Sometimes, instead of using Vietnamese, people in the communities use these parallel languages, or instead of using pure Vietnamese, people borrow more languages to express their ideas more accurately or for many other purposes.

\section{LITERATURE REVIEW}

Each society is composed of people who are in contact with each other via a dispensable means, language. Language is used to express meanings and perform various functions in different contexts and situations of our daily lives. People of different or the same settings choose one or more languages to pass across messages. 
Suzanne stated [11] that a natural phenomenon is language interference, and it is common in most countries around the world, especially in developed countries. A lot of linguists have studied and established the basis for the theory of linguistic interference.

Borrowed words are born in language interference. In common sense, the borrowed word is the word of another language that is admitted into a language and is localized (Ho Le, [3]).

According to Anthony C. Oha [8], language interference is an inevitable process when a person uses a second or foreign language. The mother tongue is added, and the foreign language is borrowed during the interfering process. From time to time, the borrowed language will be used as a mother tongue.

The language activities of residents from that dawn period of the country, according to Bui Khanh The [1], took place through diglossia, or bilingualism in the process of language exposure in the form of speech. The process of contact becomes richer, the diglossia, bilingual and multilingual forms become more and more diverse.

Urieleinreich's [12] argues that when many bilingual people use the second language, the second language's vocabulary often appears in the first language, and under the influence of linguistic contact and bilingual phenomenon, the borrowed language was born.

Nguyen Thi Hue [5], in language contact, said that the first language affects the second language. This effect is called interference or movement. Interference appears in all areas: phonology, phonetics, morphology, lexicology, syntax, and semantics.

Blom and Gumperz [9], studying the interference between English and Spanish, said that the language borrowed in language interference is a behavior that reflects the concepts of national identity and community trust.

In Nguyen Kien Truong's opinion [6], the switched language appears in families and in society in Vietnam. The trend is increasing as English is becoming more and more popular in Vietnam.

Do Huu Chau [2] wrote the work "Language contact leading to switched language and language borrowing". According to him, there is no pure language and no borrowing. This process enriches the language of each nation.

Ho Dac Tuc [10] stated that both social dynamics and individual dynamics affect the practice of language interference among young people. The author argues that useful language interference in social communication effectively conveys knowledge.

Via the media, especially on websites, many people condemn the language interference of "abusing foreign languages" or "Vietnamese language is distorted. Authors Ha Mi - Minh Luan in Thanh Nien newspaper (April 13, 2012) lists many examples of switching language, the results of language interference, and recommend that Vietnamese is at stake.

\section{METHODS}

The paper is compiled based on the following methods:

a. Theoretical research methods: survey, comparative, contrastive, analysis, synthesis

b. Practical research methods:

- Direct observation method: observing the communities in Bac Lieu.

- The data collected from Bac Lieu Department of Statistics, Bac Lieu newspaper, interviews with Bac Lieu people, and listening to public conversations.

- Methods of analysis, summarizing experience: researching and reviewing the results to draw useful conclusions.

\section{RESULTS AND DISCUSSION}

Vietnamese in Bac Lieu is under the influence of English, Chinese, Khmer, French, and Russian, etc. Many words which are borrowed from these languages are in daily use in this land nowadays.

4. 1. Borrowed words are of Khmer origin

Tran Phong Dieu [7] said that the borrowed words are related to the administrative names and things of the Khmer: Soc (hamlet, village), lung (in Khmer means "wide field"), luc (in Khmer language means "the monk at the pagoda") xa rong (xa-rong), ca rang, a kind of stove (âng kran), cần xé (canh che), cù nèo (tickle), mắm bồ hóc (brô-hok), bao bằng bàng (ca-rông), cà-om, a kind of earthen pot (kơ-om), a bottle for fishing (lop).

The borrowed words are related to animals and plants: the palm tree (thnôt), field (bâng), rivermouth (piam), linh fish (trây linh), chot fish (trây cân-chôh), ho fish (trây hô), tortoise (an-đơk), gooseberry tree (căn tuôt), mulberry tree (ping pông), ca na fruit (kna).

In Bac Lieu many places with origins in Khmer are still seen via the names such as Tra Kha, Xiem cang (belonging to Bac Lieu city), Soc Don, Tra Khua, Co Thum, Tra Ban, Cai Gia, Tra Van, ... (belonging to Vinh Loi district). 


\subsection{Borrowed words are of Chinese origin}

According to the book "Bac Lieu formerly and now", Bac Lieu in Chinese means "poor land" (Bu Leo).

Tran Phong Dieu also stated that many words borrow Chinese ones. At the most are the names of the dishes: bò pía (which is thinly wrapped with small vegetables, shrimp, meat); dầu cháo quẩy (du chá quỹ); hủ tiếu (cốc điều); lục tàu xá (green beans, ie. green bean soup); lẩu (lô, hotpot); lạp xưởng (sausage); ngầu bín (ox's penis dish); tả pín lù (tạp bỉnh lô); thèo lèo (trà liệu).

In business and communication, the following words are borrowed: chạp phô (grocery stores); chánh hẩu (genuine); tẩm quất (đản cốt); tứ chiếng (four directions, everywhere people gather).

There is an interesting mix of languages among peoples in the folk song. Each nation contributes to one voice in this area, making it more diverse, richer and more attractive.

Gió đúa chú tüng tùng tung (The wind brings about a nice guy)

Gặp chị bán gùng na nả nị ơi (Meeting a ginger-selling girl, he calls her dear)

According to Tran Phong Dieu [7], the verse includes reiterated words "tửng từng tưng, na nả" contains and indicates Uncle Tung, Miss $\mathrm{Na}$ in Cantonese and Chaozhou language. "Tung" is the Chinese sound of "Tang". The Chaozhou people claim to be Từng Náng, named after the Tang Dynasty, a brilliant dynasty of China. We understand that in the first sentence, the wind raises the joy from the heart of the Chaozhou uncle (Từng Náng) when meeting the girl "Nị", the pronoun indicating the second person according to the sound of Cantonese, "na" is a female similar to the last word of the Vietnamese sentence using the word: hey, okay ... The verse shows Vietnamese souls, Hoa souls intertwining, and uncle, tung, Miss, dear ... contain emotional affection through the reiterated words "tửng từng tưng", "na nả nị". How magical!

Not meeting each other, they wait for each other:

Trời mưa muỗi cắn máng cà (In a rain, mosquitoes bites me)

Chờ cho ến xại lên bờ khuôi huôi (I wait

until water spinach becomes in blossom)

And two folk songs of pure Vietnamese:

- Chò anh cho hết súc chò̀ (I have to wait long for you)

Chờ cho rau muống lên bờ trổ bông (I wait until water spinach becomes in blossom)
- Trời xanh đất đỏ kinh xanh (blue sky, red soil, green canal)

Đia bu muỗi cắn làm anh nhớ nàng (leeches gathering, mosquitoes biting, I miss you)

"Máng cà" is actually "máng cả". "Cả" means "bite". "Cả" is pronounced "cà" according to sonar rule "six-eight". "Én xại" means water spinach. "Khuôi huôi" is flower-blooming. The folk song shows a hangover and anxiously waiting. In the space where the mosquitoes are chirping, when water spinach grows on the fields, flowering love with hope.

\subsection{Borrowed words are of French origin}

The process of contact with French civilization lasted only less than two hundred years, but the words borrowed from the French language are very numerous. The number borrowed from this language is significant.

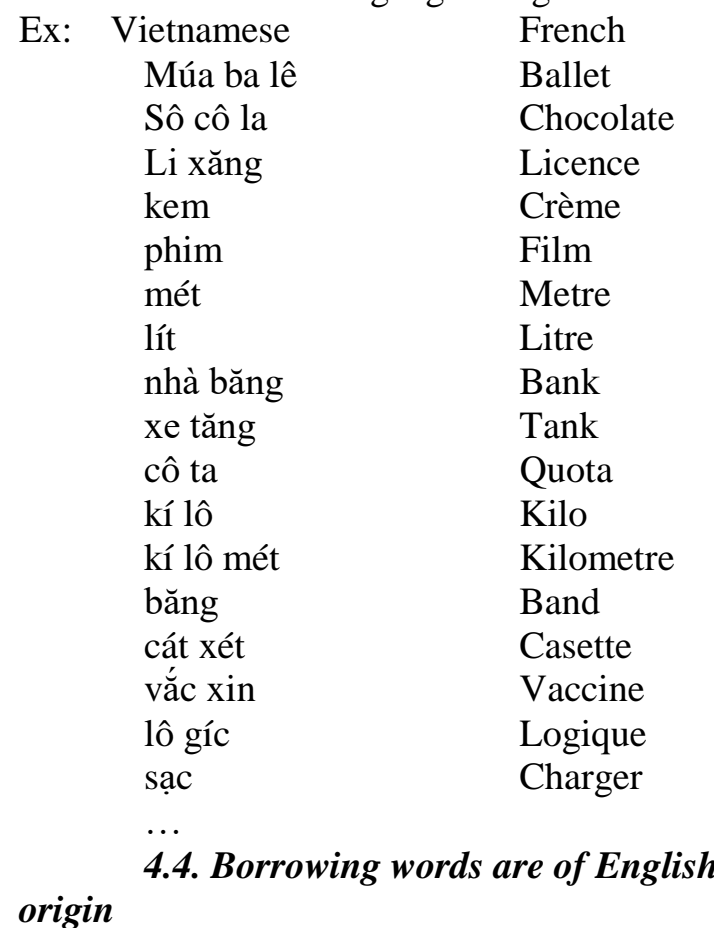

Contacting English-American words for less than a hundred years, the words borrowed from this language are increasing, and today, English loan words are constantly increasing and gaining the most in European- American languages.

\begin{tabular}{|c|c|c|}
\hline \multirow[t]{7}{*}{ Ex: } & Vietnamese & English \\
\hline & Ti vi & TV (television) \\
\hline & rock & Rock (music) \\
\hline & pop & Pop (music) \\
\hline & chip & Chip \\
\hline & internet & Internet \\
\hline & ba (quầy rượu) & Bar \\
\hline
\end{tabular}

Currently in Vietnam, English loan words are popular in many fields. The most obvious is the media filled with words such as: VTV, teen, nude 
fashion, catwalk, body suit trend, hot girl, hot boy, forum, live show, style, fan, game, shock, concert, bye, gallery, etc.

According to Hua Bich Thuy [4], the word borrowed in music tends to prevail. For example, many singers and composers like to add English to their names, such as Noo Phuoc Thinh, Wanbi Tuan Anh, Nakun Nam Cuong, Nukan Tran Tung Anh, Reno Binh, Hamlet Truong, Elly Tran, Angela Phuong Trinh, Cuong Seven, etc. Even many singers with full English names like Themen, V. Music, Sam, Kelly, Emily, Tim, Suboi, Mr.A, Mr.T, Yanbi, Lil'Knight, Young Uno, Andree ... There is a 365 band with all members using English names: Issac, Jun, Tronie, ST and Will.

In business, borrowed words in towns and cities are also not small. Many buildings and shops have both Vietnamese and English names, such as Golden Lake, Diamond Plaza, Rising Dragon, Yougurt Space, Hot and Cold, Ice Fruzz, Passio, Arlon Coffee, Shop 4 Men, Baby's shop, New World Hotel, Caravelle Hotel, Hung Vuong Plaza, Mother and Baby Shop, Happy Tom Restaurant, Office Lunch ... Most stores prefer to use "Sale, Sale off up to ...\% rather than Vietnamese words "Giảm giá", "giảm giá đến" or" New arrival "instead of "Hàng mới về" in even less frequented places for foreign customers.

In science and technology, science workers are often fluent in foreign languages, so borrowings are used a lot. The most common English words mixed in Vietnamese such as laptops (laptops), cameras (camcorders), CPUs (computer processors), computers (computers), games (games), on (turn on), off ( turn off), board (table), series (series), mass [production] ([mass production] / large volume), etc.

In everyday conversation, people like to abuse many switching languages such as: "Today you" héppy "(happy) too much", or "Today looks" kiu "(cute) too much" when complimenting colleagues. In many companies, people are used to the conversation: "The company" complen "(complain), I was" explen "(explained) to the price of "phich"(fix) and they still called" expen " (expensive). Next "Cần trắc" (contract) is not definitely "sua" (sure). Or an excerpt: "Do you book (book) a room? Do you choose a single or double room (phòng đơn or đôi). Are you sure (Anh sure chứ)? Can you fix (có thể fix) the exact arrival date? In the case of delay aircraft (hoãn chuyến) or change the plan you must confirm (xác nhận) for me".

The following dialogs templates have become popular in Bac Lieu University classes:
Dialog 1:

A: Mình mới search được một file PDF về kĩ năng thuyết trình hay lắm.

B: Vậy hả? Bạn nhớ up lên mail của nhóm để mọi người down về đọc nha!

A: $O K$.

Translated:

A: I just found a PDF file about good presentation skills.

B: Is that so? Remember to upload the group's mail so everyone can download it to read it!

A: OK.

Dialog 2:

C: Lớp trưởng mới post hình bạn gái trên facebook đó, thấy chưa?

D: Uhm, một hot girl học chung lớp tiếng Anh. Nhìn cute ghê!

Translated:

C: The new monitor posted a picture of his girlfriend on facebook, see?

D: Uhm, a hot girl who shares an English class. Look cute!

It is worth noting that there is a part of young people who create their own ways based on a certain language, usually, their mother tongue, thus seriously violating the phonetic and grammar rules of the language source. For example, Know just die (biết chết liền), Like is afternoon (thích thì chiều), No four go (Vô tư đi), Sugar sugar Ajinomoto Ajinomoto (đường đường chính chính), no see the mother (no thấy mẹ), no star where (không sao đâu), die up die down (chết lên chết xuống), in hit line - out how time (uống vào hai lít - ói ra hai thau), etc.

According to a survey conducted by students in Bac Lieu University in 2017, the use of English loan words takes place among people who know foreign languages and among people who do not know foreign languages, as follows:

\begin{tabular}{|c|c|c|c|c|}
\hline $\begin{array}{l}\text { Frequency } \\
\text { of using foreign } \\
\text { languages }\end{array}$ & $\begin{array}{r}\mathrm{Tl} \\
\text { know } \\
\text { lang }\end{array}$ & $\begin{array}{l}\text { se who } \\
\text { reign } \\
\text { ages }\end{array}$ & $\begin{array}{r}\mathrm{T} \\
\text { don' } \\
\text { fo } \\
\text { lang }\end{array}$ & $\begin{array}{l}\text { ne who } \\
\text { now } \\
\text { gn } \\
\text { ges }\end{array}$ \\
\hline Always & $\%^{3}$ & \multirow{2}{*}{$\underset{28 \%}{\Rightarrow}$} & $\%^{2}$ & \multirow{2}{*}{$5 \%$} \\
\hline Often & $\%^{25}$ & & $\%^{3}$ & \\
\hline Sometimes & \multicolumn{2}{|c|}{$52 \%$} & \multicolumn{2}{|c|}{$53 \%$} \\
\hline Rarely & \multicolumn{2}{|c|}{$19 \%$} & \multicolumn{2}{|c|}{$38 \%$} \\
\hline Never & \multicolumn{2}{|c|}{$1 \%$} & \multicolumn{2}{|c|}{$4 \%$} \\
\hline
\end{tabular}

The survey also shows different levels of using switching language in different places in Bac Lieu city:

\begin{tabular}{c|c}
$\begin{array}{c}\text { Places where switch- } \\
\text { code is used }\end{array}$ & Percentage \\
\hline
\end{tabular}




\begin{tabular}{|l|c|}
\hline Schools & $32 \%$ \\
\hline Media & $12 \%$ \\
\hline Daily dialogs & $51 \%$ \\
\hline Others: & $5 \%$ (Total) \\
Parks & $1 \%$ \\
Meetings & $1 \%$ \\
Social nets & $2 \%$ \\
Billboards & $1 \%$ \\
\hline \multicolumn{1}{|c|}{ 4.5. Borrowed words are of Russian } \\
origin
\end{tabular}

During the war against French colonialists and later American imperialists, we received great support from the Soviet Union. Although the access to Russian is very short (especially in Bac Lieu), and only Vo Thi Sau High School and Bac Lieu University is the only two places that have taught Russian and Vietnamese also borrowed a lot of Russian words.

$\begin{array}{lll}\text { Ex: } & \text { Russian } & \text { Vietnamese } \\ \text { Ca chiu sa } & \text { dàn hỏa tiễn (Cachusa) } \\ \text { Pi ri xtroi ka } & \text { đồi mới (doimoi) } \\ \text { Gláx not } & \text { công khai (glasnost) } \\ \text { Bôn sê vích } & \text { Phe đa số (bolsevich) } \\ \text { Men sê vích } & \text { Phe thiểu số (mensevich) } \\ \text { Xô viết } & \text { Hội đồng (council) } \\ \text { Ma tri ốt xka } & \text { Búp bê Nga (matriotska) } \\ \text { Rúp } & \text { Đơn vị tiền Nga (rouble) }\end{array}$

There is a joke about the fact that some Lê family mistook that they had relatives with Lenin. Because, according to them, Lenin they know, they see on photos and posters, also has surname Lê!

4.6. An interesting mixed picture in preparing food in Bac Lieu

Interestingly, in Bac Lieu nowadays, a mixed picture in preparing food may be seen through the following formula of cooking different dishes. The foods prepared by different peoples are shown as follows.

\begin{tabular}{|c|c|c|c|c|c|c|c|c|c|}
\hline $\begin{array}{l}\text { Ways } \\
\text { of } \\
\text { prepa } \\
\text { ring }\end{array}$ & $\begin{array}{l}\text { Wi } \\
\text { th } \\
\text { wat } \\
\text { er }\end{array}$ & $\begin{array}{l}\text { Wi } \\
\text { th } \\
\text { So } \\
\text { me } \\
\text { wat } \\
\text { er }\end{array}$ & $\begin{array}{l}\text { Wi } \\
\text { th } \\
\text { mu } \\
\text { ch } \\
\text { oil }\end{array}$ & $\begin{array}{l}\text { Lit } \\
\text { tle } \\
\text { oil }\end{array}$ & $\begin{array}{l}\text { fi } \\
\text { re }\end{array}$ & $\begin{array}{l}\text { N } \\
\text { ot } \\
\text { O } \\
n \\
\text { fir } \\
\text { e }\end{array}$ & $\begin{array}{l}\text { Long } \\
\text { durat } \\
\text { ion }\end{array}$ & $\begin{array}{c}\text { Short } \\
\text { durat } \\
\text { ion }\end{array}$ & $\begin{array}{l}\text { Not } \\
\text { es }\end{array}$ \\
\hline cook & + & - & - & - & - & + & - & + & \\
\hline $\begin{array}{l}\text { Stir- } \\
\text { fry }\end{array}$ & - & + & - & + & - & + & - & + & \\
\hline $\begin{array}{c}\text { Deep } \\
\text { fry }\end{array}$ & - & - & + & - & - & + & - & + & \\
\hline Grill & - & - & - & - & + & - & - & + & \\
\hline boil & + & - & - & - & - & + & - & + & \\
\hline
\end{tabular}

\begin{tabular}{|c|c|c|c|c|c|c|c|c|c|}
\hline stew & + & - & - & - & - & + & + & - & \\
\hline scald & + & - & - & - & - & + & - & + & \\
\hline roast & - & - & - & + & + & - & - & + & \\
\hline reheat & - & + & - & - & - & + & - & + & \\
\hline $\begin{array}{c}\text { smok } \\
\mathrm{e}\end{array}$ & - & - & - & - & - & - & + & - & $\begin{array}{l}\text { Ov } \\
\text { er } \\
\text { fire }\end{array}$ \\
\hline singe & - & - & - & - & - & - & - & - & $\begin{array}{l}\text { Insi } \\
\text { de } \\
\text { fire }\end{array}$ \\
\hline
\end{tabular}

How to prepare food: Cook, Boil, Simmer, Fry, Roast (English and French), Toast, Bake, Singe (Khmer), Steam, Grill, Pop (English), Torrefy, Smoke (Russian), Stew, Distil, Dry, Warm up, Heat, Reheat, etc.

\section{CONCLUSION}

Languages used in Bac Lieu are very abundant to meet the requirements of contacts for business, learning, working, and other communications. Besides Vietnamese used by most of the people, English, French, Russian, Chinese, Khmer, etc., are being used increasingly.

Language-communication develops in the integration process. When peoples come together, they will share the preeminent nuances in their language. The sounds, words, words, and semantics are borrowed to enrich the mother tongue. The interference process will constantly grow and develop more and more to supplement the mother tongue language.

There is, however, a need to refine the necessary words, phrases, and semantics. The switching language sometimes shows the abuse of the user to prove that he or she is a "wise learner". This is an unnecessary borrowing, causing the mother tongue to be distorted and monstrous.

It is impossible to float borrowing other languages. A language science department needs to monitor and shape the use of borrowed languages into Vietnamese. Every year, a book will publish new words and regulate how to use these words. Thereby, we will make Vietnamese become more and more beautiful.

\section{REFERENCES}

Vietnamese:

1. Bùi Khánh Thế, Ngôn ngữ học tiếp xúc và tiếp xúc ngôn ngữ ở Việt Nam, Nxb Đại học Quốc gia Tp. HCM. (P5, 2016) 
2. Đỗ Hữu Châu, Tù vụng học Tiếng Việt. Nhà xuất bản Đại học quốc gia. (Vietnamese Vocabulary, p. 95, 2004)

3. Hồ Lê, Vấn đề cấu tạo từ của tiếng Việt hiện đại. NXB Khoa học Xã hội (p. 159, 1976)

4. Hứa Bích Thủy, Ngôn ngữ chèn và sự ảnh hưởng đối với tiếng Việt, Hội thảo Khoa học Quốc tế lần III, Viện Ngôn ngữ học (2017).

5. Nguyễn Thị Huệ, Tiếp xúc ngôn ngữ giữa tiếng Khmer với tiếng Việt (trường hợp tỉnh Trà Vinh). Khoa học xã hội và nhân văn, số 02 , tháng 9 năm 2011.

6. Nguyễn Kiên Trường, Tiếp xúc ngôn ngữ ở Việt Nam. NXB Khoa học Xã hội. (2005)

7. Trần Phỏng Điều, Sự giao thoa ngôn ngữ giữa các dân tộc ở Nam bộ. Văn nghệ Tiền Giang. (2012)

\section{English:}

8. Anthony C. Oha, Introduction to Sociolinguistics. National Open University of Nigeria (P.124, 2010)
9. Blom and Gumperz, Social Meaning in Linguistic Structures: Code Switching in Northern Norway." In: John Gumperz and Del, (P. 45, 1972) 10. Ho Dac Tuc, Vietnamese-English Bilingualism, Patterns of Code-switching, Penguin Publishing House. (P.24, 2003)

11. Suzanne Rommaine, Bilingualism. CUP. (P. 98, 1988)

12. UrielWeinreich's, Languages in Contact. CUP. (P.156, 1953)

\section{Biodata}

As a senior lecturer at Sai Gon University, Truong Van Anh also gives lectures at other universities. His supervised students doing their scientific research have won some national prizes. His scientific articles have been published in scientific journals and proceedings. Especially, he has had over 50 books in English published by various publishing houses. 